\title{
The Soft Skill Elements in an On-Job Training (OJT) (Organisation) Assessment Rubric for Construction Technology Students in Malaysian Vocational Colleges
}

\author{
Musid, N.A. ${ }^{1}$, Affandi, H.M. ${ }^{2 *}$, Abas, N.H. ${ }^{3}$, Kamal M.F.M. ${ }^{4}$ \\ ${ }^{1}$ Department of Teaching and Learning Innovation, Faculty of Education, The National University of Malaysia, Bangi, \\ 43600 MALAYSIA
}

${ }^{2}$ Department of Engineering Education and Built Environment Research, Faculty of Engineering and Built Environment, The National University of Malaysia, Bangi, 43600 MALAYSIA

${ }^{3}$ IBS Cluster, Jamilus Research Centre, Faculty of Civil and Environmental Engineering, Universiti Tun Hussein Onn Malaysia, Batu Pahat, 86400 MALAYSIA

${ }^{4}$ Department of Engineering Technology, Faculty of Technical and Vocational, Sultan Idris Education University, Tanjong Malim, 35900 MALAYSIA

DOI: https://doi.org/10.30880/jtet.2019.11.03.011

Received $26^{\text {th }}$ August 2018; Accepted $09^{\text {th }}$ September 2019; Available online $30^{\text {th }}$ September 2019

\begin{abstract}
During on-Job Training (OJT), students are assessed by using the OJT (Organisation) assessment rubric. However, soft skill elements in the current assessment rubric are quite general in assessing students according to the job scope for Diploma in Construction Technology. The items in the current assessment rubric are not specific to assess soft skills of site supervisors which are important in the construction industry. Therefore, this study aims to identify the soft skill elements for OJT (Organisation) assessment rubric for Construction Technology students. The research design for this study is a survey that was carried out quantitatively through questionnaires involving contractors of G4 to G7 as the population of this study and administered to 180 contractors by using simple random sampling. After document analysis and expert validation process, five items were selected to be the constructs of soft skills and 21 items were chosen to be the elements for soft skills. From the Rasch Model analysis which referred to the Infit and Outfit values, one item was discarded which was Item C05 because it showed out-of-range values for both the Mean Square Infit and Outfit as well as the Z Standard value for Infit and Outfit. This finding was validated by experts. As a result, only 20 elements were accepted to be elements of the OJT (Organisation) assessment rubric. However, according to the item polarity analysis, all 21 elements were accepted to be elements in the OJT (Organisation) assessment rubric. The data analysis also indicated that both item and person reliability were good. The five constructs identified from this study were communication skill, critical thinking and problemsolving skill, teamwork, ethics and professional moral and leadership skill. In conclusion, this study was able to identify specific soft skills for site supervisors which could help to solve the problem of the general assessment elements in the current OJT rubric. Students may use these elements as a reference for job scope during OJT. Therefore, it is suggested to conduct a study for determining the descriptors for the soft skill elements
\end{abstract}

Keywords: On job training, assessment rubric, diploma in construction technology, soft skills.

\section{Introduction}

The construction industry is an important industry that plays a vital role in the socio-economic growth of a country 
(Abdul Rahman, Memon, \& Karim, 2013). The low performance level of skilled workers is seen to be a major factor which contributes towards inefficient construction project productivity (Zannah, Latiffi, Raji, Waziri \& Mohammed, 2017). Training and education at the organisation level are one of the factors that help to improve productivity in the construction industry (Zhan, Pan, Javed, \& Chau, 2017). Education is also related to competence and expertise (Medeshova, Amanturlina, \& Sumyanova, 2016). In Malaysia, vocational colleges are one of the educational institutions that offer a Diploma in Construction Technology which provides education and training to students to produce site supervisors (Bahagian Pendidikan Teknik dan Vokasional, 2017).

Competency also has its relation to knowledge, skills, and attitude (Long, Ibrahim, \& Kowang, 2013). Students' skills, especially soft skills support their readiness to perform practical-theoretical activities based on life experience and gained knowledge (Yuanxing, 2014). Soft skills can be categorised as interpersonal and intrapersonal (Vijayalakshmi, 2016). Without soft skills, there are very little chances of achieving success, even with the best academic qualifications (Bhanot, 2009). Lacking in soft skills can result in unemployment, even among higher institution graduates (Hasliza, 2003). Existing literature shows evidence of a soft skill gap among construction graduates (Mahasneh, 2016).

The lack of soft skill elements such as lack of communication plan is one of the key factors causing construction time overrun (Famiyeh, Amoatey, Adaku, \& Agbenohevi, 2017). Meanwhile, another element of soft skill is the low speed of decision making which causes delays in construction projects (Marzouk \& El-Rasas, 2014). Based on a study by Abd El-Razek, Bassioni, and Mobarak (2008), teamwork which is another element of soft skills is required to reduce project delay. Poor site management and supervision which is under leadership skill is one of the soft skill elements that contributes to project delay (Marzouk \& El-Rasas, 2014). Time overrun is one effect of unethical professional practices on construction project performance (Inuwa, Usman, \& Dantong, 2015) whereas ethics and professional morals is another element of soft skills. In the construction industry, workers with soft skills may assist in avoiding time overrun as it can trigger some serious problems in the future.

According to Kluger and DeNisi (1996), three theories that can guide the cognitive, emotional and social aspects of soft skills are control theory, goal setting theory, and attribution theory. These three theories are chosen in developing the soft skill elements. According to Gibb (2014), control theory emphasises more on cognitive and emotional aspects where the self is dominant. Goal setting theory comprises of cognitive, emotional and social aspects related to soft skill performances where the social aspect is dominant. Meanwhile, the attribution theory focuses on the self and social aspects. Therefore, the cognitive, emotional and social aspects of soft skills should be put into consideration when assessing students' competency.

Students' soft skills may be improved through industrial training (Syaira Jihan, 2016). In the Malaysian vocational colleges, industrial training is called On Job Training (OJT). OJT refers to the compulsory training for students in a real workplace at government or private agencies for five months after they completed Semester 8 (Pengurusan Akademik Bahagian Pendidikan Teknik dan Vokasional, 2017). According to the Vocational College Standard Curriculum, there are seven elements of soft skills. The elements are communication skill, critical thinking and problem-solving skill, teamwork skill, lifelong learning and information management, entrepreneurship skill, ethics and professional morals, and leadership skill (Bahagian Pendidikan Teknik dan Vokasional, 2017).

Soft skills of Malaysian vocational college students are assessed during OJT using an assessment rubric (Pengurusan Akademik Bahagian Pendidikan Teknik dan Vokasional, 2017). The current OJT (Organisation) assessment rubric focuses more on the soft skills than technical skills (Pengurusan Akademik Bahagian Pendidikan Teknik dan Vokasional, 2017). Furthermore, the soft skill elements in the assessment rubric are generic in nature and not specific to the job scope in the Construction Technology field (Pengurusan Akademik Bahagian Pendidikan Teknik dan Vokasional, 2017). As a result, students may not acquire the knowledge, skill, and attitude needed in the construction industry since what is assessed is usually not learned. Thus, the aim of the Diploma in Construction Technology which is to produce competent site supervisors may not be achieved. This in turn will reflect on the quality and productivity within the construction industry that could possibly bring a negative image to the industry.

Therefore, a specific assessment rubric is necessary and this study aimed to identify the soft skill elements that are needed to be included in the OJT (Organisation) assessment rubric to produce a valid and reliable assessment of students' performance in the construction industry. The Rasch Model analysis was used to check the content validity of the soft skill elements by examining the polarity item and item fit value as well as to identify item reliability and person reliability of the soft skill elements.

\section{Methodology}

The research design chosen in this study is a survey with quantitative data gathered through a questionnaire. The population of this study involved 17818 contractors G4 to G7 because one of the prerequisites of a certificate of registration for contractors G4 to G7 is a diploma in construction (Lembaga Pembangunan Industri Pembinaan, 2017). As a result, contractors G4 to G7 may be able to identify the suitable job scope for Diploma in Construction Technology students during OJT.

The sampling method chosen for this study was the simple random sampling method which means individuals chosen to be sampled represented the population and any bias in the population would be equally distributed among the 
people chosen (Creswell, 2012). The selection of assessment elements was carried out using data obtained after the analysis using the Rasch Model analysis method. The Rasch analysis was used as it is able to yield a variety of important psychometric findings that serve as a useful diagnostic tool for discerning the quality of a test item and the scores produced (Royal, Gilliland, \& Kernick, 2014). Therefore, the number of samples can be referred to in Table 1 below (Linacre, 1994).

Table 1- Sampling Size and Logit for Item Calibration

\begin{tabular}{cccc}
\hline $\begin{array}{c}\text { Item Calibrations Stable } \\
\text { Within }\end{array}$ & Confidence & Minimum Sample Size Range & $\begin{array}{c}\text { Size for Most } \\
\text { Purposes }\end{array}$ \\
\hline \pm 1 logit & $95 \%$ & $16-36$ & 30 \\
\pm 1 logit & $99 \%$ & $27-61$ & 50 \\
$\pm 1 / 2 \operatorname{logit}$ & $95 \%$ & $64-144$ & 100 \\
$\pm 1 / 2 \operatorname{logit}$ & $99 \%$ & $108-243$ & 150 \\
\hline
\end{tabular}

Source: (Linacre, 1994)

This study used item calibration with $\pm 1 / 2$ logit and $95 \%$ confidence level, thus the minimum size appropriate for this study was 100 . The questionnaires were distributed during the training organised by the Construction Industry Development Board. This method of distributing questionnaires was chosen to ensure a $100 \%$ return rate. The respondents involved in this study were contractors G4 to G7. The total respondents were 180 people, and they needed to answer the questionnaires in 30 minutes. As a result, the returning rate was $100 \%$.

This study discusses the soft skill elements that have been identified through document analysis and expert validation. Documents used for document analysis were Course Learning Outcome for Diploma in Construction Technology, Level 3 Construction Site Supervisory and Management of National Occupational Skills Standard (NOSS), Vocational College Standard Curriculum and Course Learning Outcome for OJT. There were four experts from academia and experienced construction practitioners involved in this study. The expert validation was conducted in two phases. The first phase was to identify subconstructs and elements for the OJT (Organisation) assessment rubric. The second phase was to reconfirm the subconstructs and elements for OJT (Organisation) assessment rubric. After the expert validation process, only five elements were accepted to be the subconstructs for measuring soft skills among Construction Technology students which were communication skills, critical thinking and problem-solving skill, teamwork, ethics, and professional moral, and leadership skill. The questionnaire consisted of two sections. Section A was for gathering the respondents' demographic data and Section B was data on the soft skills construct. Table 2 shows the subconstructs of soft skills and the number of items for each subconstruct.

Table 2- Subconstructs and number of Item for the associated constructs

\begin{tabular}{cc}
\hline Subconstruct & Number of Items \\
\hline Communication Skill & 5 \\
Critical Thinking and Problem-Solving Skill & 3 \\
Teamwork & 4 \\
Ethics and Professional Moral & 7 \\
Leadership Skill & 2 \\
\hline
\end{tabular}

The 4-point scale used comprised of extremely not important (1), not important (2), important (3) and extremely important (4). A 4-point scale was chosen because if an odd scale was used, it will provide a middle choice and most of the respondents will choose the middle choice (Bambang \& Wahyu, 2013).

\section{Result}

Although the total respondents were 180, only 164 questionnaires were analysed using the Rasch Model analysis method. Sixteen respondents were excluded as they were extreme persons. This meant that they answered four which was extremely important on all items in the questionnaires.

\subsection{Item Fit}

The appropriateness of items in measuring the constructs can be examined through the Mean Square Infit and Mean Square Outfit of each item (Md Yunos et al., 2017). The accepted value for Mean Square Infit and Outfit was between 0.50 to 1.50 (Linacre, 1994), whereas the accepted value for Z Standard was in the range of -2.0 to 2.0 (Linacre, 1994). Table 3 below shows the value of item fit for 21 items in the OJT (Organisation) assessment rubric for Diploma in Construction Technology.

Table 3- Item Fit 


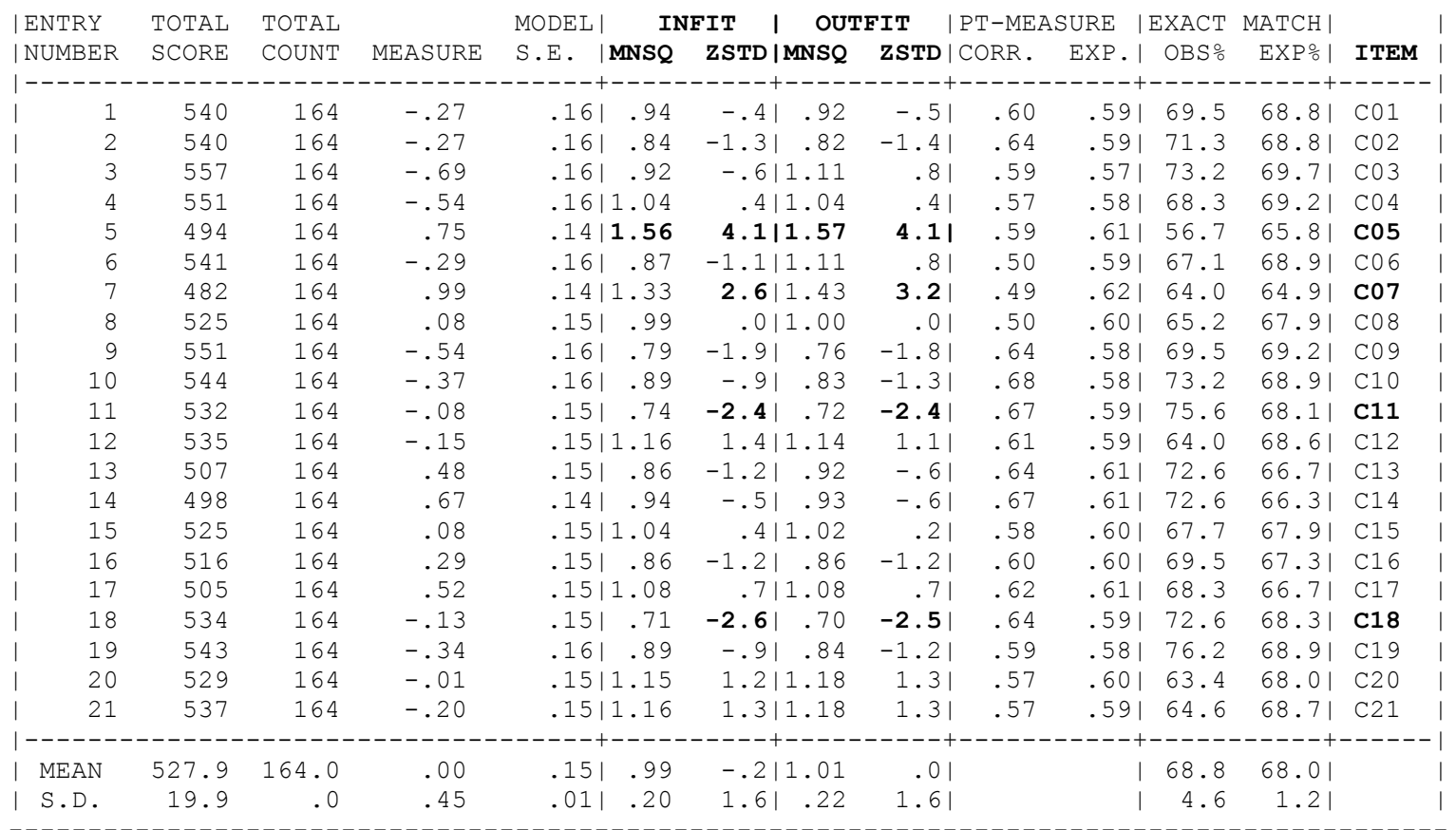

Based on Table 3, Item C05 which was coordinate with authorities showed the value of Mean Square Infit and Outfit that was out of the accepted range value. The Mean Square Infit value was 1.56 while Mean Square Outfit value is 1.57. The value of Z Standard Infit and Outfit for Item C05 also showed an out-of-accepted range value. Both Z Standard Infit and Outfit value was 4.1. Therefore, Item C05 should be referred to experts to identify whether this item should be maintained, discarded or modified. After referring Item $\mathrm{C} 05$ to four content experts, all experts agreed that Item C05 should be discarded from the rubric with 100\% agreement percentage. According to Mohd Noah \& Ahmad (2005), if the percentage of content validity achievement is more than $70 \%$, then it shows good content validity. Therefore, Item $\mathrm{C} 05$ which was coordinate with authorities was discarded from being an element of OJT (Organisation) assessment rubric.

Next, Item C07, Item C11, and Item C18 showed out-of-range values for Z Standard Infit and Outfit. Table 4 shows the items and out of range values for Z Standard Infit and Outfit.

Table 4- Items and Z Standard Infit and Outfit

\begin{tabular}{|c|c|c|c|}
\hline Item & Element & Z Standard Infit & Z Standard Outfit \\
\hline $\mathrm{C} 07$ & Perform taking off for various types of building trades & 2.6 & 3.2 \\
\hline $\mathrm{C} 11$ & $\begin{array}{l}\text { Organise civil and structural work method statement } \\
\text { implementation }\end{array}$ & -2.4 & -2.4 \\
\hline $\mathrm{C} 18$ & $\begin{array}{c}\text { Monitor civil and structural works progress in accordance } \\
\text { with quality requirements }\end{array}$ & -2.6 & -2.5 \\
\hline
\end{tabular}

However, these three items showed accepted range values for Mean Square Infit and Outfit. According to Linacre (2005), if the Mean Square value is accepted, the Z Standard can be ignored (Linacre, 2005). Therefore, Items C07, $\mathrm{C} 11$, and $\mathrm{C} 18$ were maintained as elements in the OJT (Organisation) assessment rubric.

\subsection{Polarity Item}

Polarity item was conducted to determine if the same item was generated that measured the construct to be measured (Md Yunos et al., 2017). Polarity item referred to point-measure correlation (PTMEA Correlation), and the value should be between 0.20 and 0.79 Linacre (2002). Based on Table 5 below, PTMEA Correlation value was between 0.49 to 0.68 . Therefore, all items were accepted to be elements in the assessment rubric.

Table 5- Polarity Item 


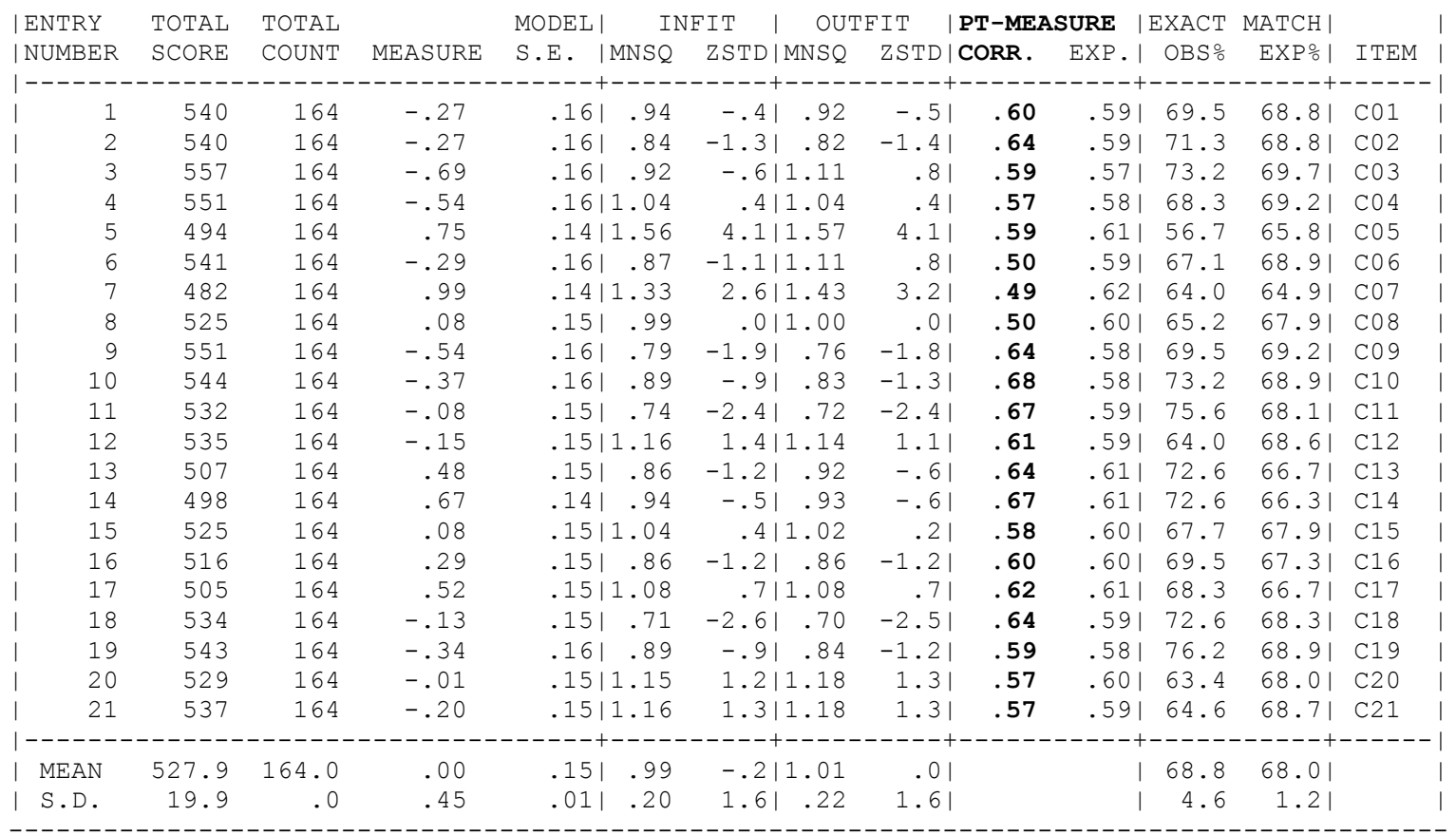

Table 6 below shows a list of 21 items which were accepted to be elements of OJT (Organisation) assessment rubric based on polarity item.

Table 6- List of Item

\begin{tabular}{|c|c|c|}
\hline Subconstruct & Item & Element \\
\hline \multirow{5}{*}{$\begin{array}{l}\text { Communicatio } \\
n \text { Skill }\end{array}$} & $\mathrm{C} 01$ & $\begin{array}{l}\text { Discuss to determine the needs for materials, machinery, equipment } \\
\text { (construction resources) based on work scheduling for demolition works }\end{array}$ \\
\hline & $\mathrm{C} 02$ & Discuss the structural work monitoring in progress report \\
\hline & $\mathrm{C} 03$ & Communicate in the team to supervise temporary facilities based on the site plan \\
\hline & $\mathrm{C} 04$ & Liaise with other site personnel \\
\hline & $\mathrm{C} 05$ & Coordinate with authorities \\
\hline \multirow{4}{*}{$\begin{array}{c}\text { Critical } \\
\text { Thinking and } \\
\text { Problem } \\
\text { Solving Skill } \\
\end{array}$} & $\mathrm{C} 06$ & Apply related knowledge and skill at the workplace \\
\hline & $\mathrm{C} 07$ & Perform taking off for various types of building trades \\
\hline & $\mathrm{C} 08$ & Identify suitable machineries and equipment for mobilisation on site \\
\hline & & \\
\hline \multirow{4}{*}{ Teamwork } & $\mathrm{C} 09$ & $\begin{array}{l}\text { Cooperate in planning for extension and renovation works based on a given } \\
\text { situation }\end{array}$ \\
\hline & $\mathrm{C} 10$ & Participate in site meeting for construction work based on master work schedule \\
\hline & $\mathrm{C} 11$ & Organise civil and structural work method statement implementation \\
\hline & $\mathrm{C} 12$ & Participate in technical meetings \\
\hline \multirow{7}{*}{$\begin{array}{l}\text { Ethics and } \\
\text { Professional } \\
\text { Moral }\end{array}$} & $\mathrm{C} 13$ & Assist in producing a civil and structural progress report for approval submissions \\
\hline & $\mathrm{C} 14$ & Prepare progress claim based on construction work variations \\
\hline & $\mathrm{C} 15$ & $\begin{array}{l}\text { Monitor civil and structural works progress in accordance with safety and health } \\
\text { requirements }\end{array}$ \\
\hline & $\mathrm{C} 16$ & $\begin{array}{l}\text { Monitor civil and structural work progress in accordance to environment } \\
\text { requirements }\end{array}$ \\
\hline & $\mathrm{C} 17$ & $\begin{array}{l}\text { Monitor civil and structural work progress in accordance with financial } \\
\text { requirements }\end{array}$ \\
\hline & $\mathrm{C} 18$ & Monitor civil and structural work progress in accordance to quality requirements \\
\hline & $\mathrm{C} 19$ & Practice quality policies and procedures in construction works \\
\hline \multirow{2}{*}{$\begin{array}{l}\text { Leadership } \\
\text { Skill }\end{array}$} & $\mathrm{C} 20$ & Supervise personnel performance \\
\hline & $\mathrm{C} 21$ & Supervise personnel discipline \\
\hline
\end{tabular}

\subsection{Reliability}

The first objective for this study was to determine person reliability and item reliability of soft skill elements. The item and person reliability and separation indices showed the extent to which the items were compatible (conform to fit) with the Rasch Measurement Model (Md Yunos et al., 2017). Table 7 shows the rating scale of instrument quality criteria for item and person reliability according to Fisher (2007). 
Table 7- Rating scale instrument quality criteria

\begin{tabular}{cccccc}
\hline Criteria & Poor & Fair & Good & Very Good & Excellent \\
\hline Person \& Item Reliability & $<0.67$ & $0.67-0.8$ & $0.81-0.9$ & $0.91-0.94$ & $>0.94$ \\
\hline
\end{tabular}

Table 8 shows the summary of the person reliability and person separation index.

Table 8- Person Reliability

SUMMARY OF 164 MEASURED PERSON

\begin{tabular}{|c|c|c|c|c|c|c|c|c|}
\hline & \multirow{2}{*}{$\begin{array}{l}\text { TOTAL } \\
\text { SCORE }\end{array}$} & \multirow[b]{2}{*}{ COUNT } & \multirow[b]{2}{*}{ MEASURE } & \multirow{2}{*}{$\begin{array}{l}\text { MODEL } \\
\text { ERROR }\end{array}$} & \multicolumn{2}{|c|}{ INEIT } & \multicolumn{2}{|c|}{ OUTFIT } \\
\hline & & & & & MNSQ & ZSTD & MNSQ & ZSTD \\
\hline MEAN & 67.6 & $21 \cdot 0$ & 2.03 & .44 & 1.01 & -.3 & 1.01 & -.3 \\
\hline S.D. & 8.2 & .0 & 1.49 & .10 & .74 & 2.0 & .73 & 2.0 \\
\hline MAX & 83.0 & 21.0 & 5.99 & 1.03 & 4.40 & 5.1 & 4.34 & 5.0 \\
\hline MIN & 34.0 & 21.0 & -2.28 & .33 & .06 & -4.5 & .05 & -4.6 \\
\hline
\end{tabular}

\begin{tabular}{llllllll}
\hline REAL RMSE & .50 & TRUE & SD & 1.40 & SEPARATION & $\mathbf{2 . 7 9}$ & PERSON RELIABILITY \\
MODEL R9
\end{tabular}

S.E. OF PERSON MEAN $=.12$

Based on the above table, person reliability value is 0.89 which indicates person reliability is in good level (Fisher, 2007). This value shows the probability of person response outcome repetition when the same test is conducted good (Aziz, 2015). Meanwhile, the person separation index is 2.79. Person separation index used to estimate the ability of an instrument to differentiate individuals into certain groups based on measured constructs (Aziz, 2015). This person separation index estimates the ability of this instrument to differentiate individuals into three groups of the measured construct is in good level. Table 9 shows the summary of the item reliability and item separation index.

Table 9- Item Reliability

SUMMARY OF 21 MEASURED ITEM

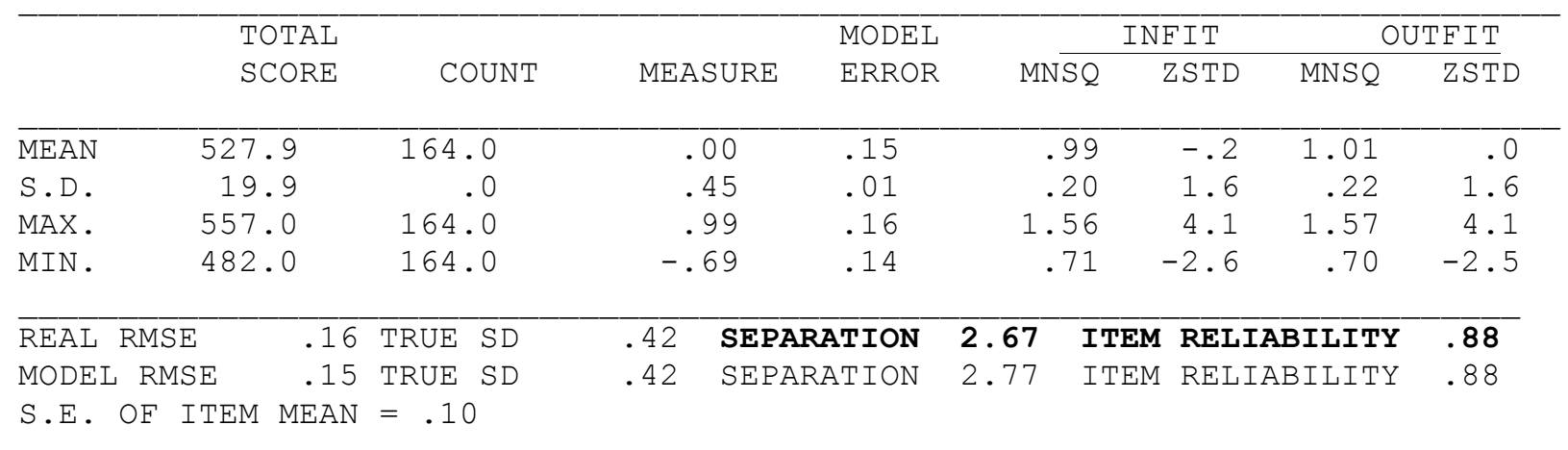

The above table showed that the item reliability value was 0.88 which indicated a good level (Fisher, 2007), meaning that the ability of the items to measure what the items are supposed to measure is good (Aziz, 2015). Meanwhile, item separation index was 2.67. Item separation index was used to estimate the person ability to separate item difficulty into a few levels based on the measured constructs (Aziz, 2015). This item separation index estimated the person's ability to separate item difficulty into three levels based on the measured construct which was in the good level.

\section{Findings and Discussion}

Soft skill elements are essential in assessing students' competency during OJT. According to Malaysia Qualification Agency (MQA) (2013), soft skills are characteristics or attributes and skills desired by an employee that are needed in the professional life which involves students and community. However, soft skill elements in the current assessment rubric are quite general in assessing students' competency. Therefore, soft skill elements are developed according to job scope in Construction Technology.

One of the developed soft skill constructs is communication skill. Without effective communication, a message can turn into error, misunderstanding, or frustration (Erozkan, 2013). Proper communication is necessary for 
construction (Ali \& Wen, 2011). The performance of supervisors depends on skilled communication with individual workers, and planning and directing the work (Ahzahar, Karim, Hassan, \& Eman, 2011).

The other developed soft skill constructs were critical thinking and problem-solving. For problem-solving, some students felt a lack of support, time and resources which negatively impacted their capacity to develop in this area (Jackson, 2015). Teamwork is also another developed soft skill construct. It is crucial to assess teamwork during OJT because lack of teamwork approach is also another weak point in the Malaysian construction industry (Ibrahim, Roy, Ahmed, \& Imtiaz, 2010). The fourth developed soft skill construct is ethics and professional moral. Employers and the industry associations commonly associate the lack of soft skills such as a positive work ethic, communication skills, team working, decision-making skill and leadership as a key factor affecting the employability of Malaysian graduates (Hanapi \& Nordin, 2014). Another developed soft skill construct is leadership skill. Higher education institution graduates were criticised because of lack of leadership (Ismail, 2011; Malhi, 2009). Therefore, these five developed soft skill constructs need to be assessed because they are fundamental in producing competent site supervisor.

Also, the elements in each construct were carefully developed based on a specific job scope in the construction industry. This will help the assessor or supervisor at the industry to assess students' performance as well as guide them during OJT. The students can also gain benefit as they may refer to the elements to know their tasks during OJT. Thus, they can prepare themselves to get excellent results for OJT. However, this OJT (Organisation) assessment rubric was developed for the Diploma in Construction Technology only and some constructs in this developed rubric were similar to other assessment rubrics for assessing performances such as communication skill, problem-solving and teamwork.

\section{Conclusion}

From the data analysis, according to the Mean Square Infit and Outfit, one item should be discarded, and experts have verified this. As a result, only 20 items were accepted to be the soft skill elements in the OJT (Organisation) assessment rubric. However, all 21 items were accepted to be elements in the assessment rubric according to item polarity. Meanwhile, both item and person reliability were good. In conclusion, this study was able to solve the issue on items in the current rubric not being specific to the job scope of site supervisors. The five constructs and 20 items identified in this developed rubric indicated that the Diploma in Construction Technology applied a comprehensive assessment to produce competent site supervisors. The five constructs were communication skill, critical thinking and problem-solving skill, teamwork, ethics and professional moral, and leadership skill. Students may use these elements as a reference for the job scope during OJT. Thus, further research is suggested to conduct for determining the descriptors for the selected soft skill elements of developed On Job Training (organisation) assessment rubric of Diploma in Construction Technology.

\section{References}

Abd El-Razek, M.E., Bassioni, H.A., \& Mobarak, A.M. (2008). Causes of Delay in Building Construction Projects in Egypt. Journal of Construction Engineering and Management, 134(11), 831-841.

Abdul Rahman, I., Memon, A. H., \& Karim, A. (2013). Significant factors causing cost overruns in large construction projects in Malaysia. Journal of Applied Science, 13(2), 286-293.

Abu Bakar Nordin. (1995). Penilaian Afektif. Kajang: MASA Enterprise.

Agensi Kelayakan Malaysia (MQA) (2013). Garis Panduan Amalan Baik: Penilaian Pelajar. Retrieved on 20 September 2017 at www.mqa.gov.my.

Ahzahar, N., Karim, N. A., Hassan, S. H., \& Eman, J. (2011). A Study of Contributing Factors to Building Failures and Defects in Construction Industry. Procedia Engineering, 20, 249-255.

Ali, A.S., \& Wen, K.H. (2011). Building defects: possible Solution for Poor Construction Workmanship. Journal of Building Performance, 2(1), 59-69.

Aziz, A. A. (2015). Asas Model Pengukuran Rasch. Bangi: Penerbit Universiti Kebangsaan Malaysia.

Bahagian Pendidikan Teknik dan Vokasional. (2017). Kurikulum Standard Kolej Vokasional. Putrajaya: Kementerian Pendidikan Malaysia.

Bambang, S. \& Wahyu, W. (2013). Aplikasi Model Rasch Untuk Penelitian Ilmu-Ilmu Sosial. Cimahi: Trim Komunikata Publishing House.

Bhanot, S. (2009). Importance of Soft Skills for an Employee and for the Organization. SIES Journal of Management, $6(1), 18-22$.

Chan, D.W.M., \& Kumaraswamy, M.M. (1997). A Comparative Study of Causes of Time Overruns in Hong Kong Construction Projects. International Journal of Project Management, 15(1), 55-63. 
Creswell, J. W. (2012). Educational Research Planning, Conducting and Evaluating Quantitative and Qualitative Research. Boston: Pearson ( $4^{\text {th }}$ Edition).

Erozkan, A. (2013). The Effect of Communication Skills and Interpersonal Problem Solving Skills on Social SelfEfficacy. Educational Sciences: Theory \& Practice 13(2): 739-745.

Famiyeh, S., Amoatey, C.T., Adaku, E., \& Agbenohevi, C. S. (2017). Major Causes of Construction Time and Cost Overruns: A Case of Selected Educational Sector Projects in Ghana. Journal of Engineering, Design, and Technology, 15(2), 181-198.

Fisher, W. P. Jr. (2007). Research Scale Instrument Quality Criteria. Rasch Measurement Transactions, 21(1), 1095.

Gibb, S. (2014). Soft skills assessment: theory development and the research agenda. International Journal of Lifelong Education 33(4):1-31

Hanapi, Z., \& Nordin, M.S. (2014). Unemployment Among Malaysia Graduates: Graduates' Attributes, Lecturers' Competency and Quality of Education. Procedia-Social and Behavioral Sciences, 112: 1056-1063.

Hasliza Hassan. (2003). Ciri-ciri Kualiti Pelajar untuk Keperluan Kerja Pada Masa Kini. Seminar Antara Industri dan Institusi Pendidikan Awam. Bangi: Universiti Kebangsaan Malaysia.

Ibrahim, A. R., Roy, M. H., Ahmed, Z., \& Imtiaz, G. (2010). An Investigation of the Status of the Malaysian Construction Industry. Benchmarking: An International Journal, 17(2), 294-308.

Inuwa, I.I., usman, N. D., \& Dantong, J.S.D. (2015). The Effects of Unethical Professional Practice on Construction Projects Performance in Nigeria. African Journal of Applied Research (AJAR), 1(1), 72-88.

Ismail, N. A. (2011). Graduates' characteristics and unemployment: A study among Malaysian graduates. International Journal of Business and Social Science, 2(16), 94-102.

Jackson, D. (2015). Employability skill development in work-integrated learning: Barriers and best practice. Studies in Higher Education, 40(2): 350-367.

Kamarudin, M. T. (2005). Tahap Keyakinan Kemahiran Generik di Kalangan Pelajar Kolej Komuniti Kementerian Pengajian Tinggi Malaysia. Johor: Universiti Teknologi Malaysia.

Kazmi, S. W. (2007). Vocational Education and Skills Development: A Case of Pakistan. SAARC Journal of Human Resource Development, 3(8), 105-117.

Kluger, A. \& DeNisi, A. (1996). The Effects of Feedback Interventions on Performance: A Historical Review, a MetaAnalysis and a Preliminary Feedback Intervention Theory. Psychological Bulletin 119(2): 254-284.

Kruger, S. (2006). Developing Non-Technical Skills through Co-operative Education. The Third V.T. Vittachi International Conference. Canada.

Lembaga Pembangunan Industri Pembinaan. (2017). Kontraktor Berdaftar Mengikut Gred dan Negeri. Kuala Lumpur: CIDB Malaysia.

Lembaga Pembangunan Industri Pembinaan. (2017). Syarat-syarat Perakuan Pendaftaran Kontraktor Tempatan $(P P K)$. Retrieved on 10 August at http://www.cidb.gov.my/images/content/pdf/cims/lampiran\%20A.pdf

Linacre, J. M. (1994). Rasch Measurement Transactions. Sample Size and Item Calibration Stability, 7(4), 328.

Linacre, J. M. (2002). Optimizing Rating Scale Category Effectiveness. Journal of Applied Measurement, 85-106.

Linacre, J. M. (2005). A user's guide to winsteps ministep: Rasch-Model computer programs. Chicago: MESA Press.

Long, C. S., Ibrahim, Z., Kowang, T. O. (2013). An analysis on the relationship between lecturers' competencies and students' satisfaction. International Education Studies, 7(1), 37-46.

Mahasneh, J. K. (2016). A Theoretical Framework for Implementing Soft Skills in Construction Education Utilizing Design for Six Sigma. Virginia Polytechnic Institute and State University: PhD Dissertation.

Malhi, R.S. (2009). The hard truth about graduate employability and soft skills. ADEPT: Higher Education Leadership Research Bulletin, 3, 45-56.

Marzouk, M.M., \& El-Rasas, T.I. (2014). Analyzing delay causes in Egyptian construction projects. Journal of Advanced Research, 5: 49-55.

Md Yunos, J., Ibrahim Mukhtar, M., Alias, M., Lee, M. F., Tee, T.K., Rubani, S.N.K., Hamid, H., Yunus, F.A.N., Sulaiman, J., Sumarwati, S. (2017). Validity of Vocational Pedagogy Constructs Using the Rasch Measurement Model. Journal of Technical Education and Training (JTET), 9(2), 35-45. 
Medeshova, A., Amanturlina, G., \& Sumyanova, E. (2016). Development of Training Skills in Students as the Precondition for Educational Competencies. International Journal of Environmental \& Science Education, 11(17): 9649 - 9656.

Mohd Noah, S., \& Ahmad, J. (2005). Pembinaan modul: bagaimana membina modul latihan dan modul akademik. Serdang, Selangor: Penerbit Universiti Putra Malaysia.

Pengurusan Akademik Bahagian Pendidikan Teknik dan Vokasional. (2017). Garis Panduan Pelaksanaan "On-The Job Training" di Kolej Vokasional. Port Dickson: Majlis Pengarah Pengetua Kolej Vokasional/SMT Kebangsaan.

Royal, K.D., Gilliland, K.O., \& Kernick, E.T. (2014). Using Rasch Measurement to Score, Evaluate, and Improve Examinations in an Anatomy Course. Anatomical Sciences Education, 7: 450 - 460.

Sambasivan, M., \& Soon, Y.W. (2007). Causes and effects of delays in Malaysian construction industry. International Journal of Project Management, 25(5), 517-526.

Shaikhah Alainati, AlShawi, S. N., \& Al-Karaghouli, W. (2010). The Effect of Education and Training on Competency. Proceeding of the European and Mediterranean Conference on Information Systems, Abu Dhabi, UAE, 12 -13 April 2010 .

Tatum, D. S. (2000). Rasch Analysis: An Introduction to Objective Measurement. Laboratoty Medicine, 31(5), 272274.

Teles, V.M. \& Oliveira, C. E. T. (2003). Reviewing The Curriculum of Software Engineering Undergraduates Courses to Incorporate Communication \& Interpersonal Skills Teaching. Software Engineering Education and Training.

Yuanxiang, G. (2014). View of Practical Education and Educating People through Practice.

Zannah, A.A., Latiffi, A. A., Raji, A.U., Waziri, A.A., \& Mohammed, U. (2017). Causes of Low-Skilled Workers' Performance in Construction Projects. Path of Science 3(6): 4.1- 4.15.

Zhan, W., Pan, W., Javed, A. A., \& Chau, K. W. (2017). Correlation Analysis of Key Influencing Factors to the Total Factor Productivity of the Hong Kong Construction Industry. Proceedings of the $21^{\text {st }}$ International Symposium on Advancement of Construction Management and Real Estate, 565-575. 